\title{
Enhancement of declarative memory associated with emotional content in a Brazilian sample
}

J.E. Frank and C. Tomaz
Laboratório de Neurobiologia, Instituto de Biologia, Universidade de Brasília, Braślia, DF, Brasil

\section{Correspondence \\ C. Tomaz \\ Laboratório de Neurobiologia \\ Universidade de Brasília \\ Caixa Postal 04631 \\ 70910-900 Brasília, DF \\ Brasil \\ Fax: + 55-61-274-1251 \\ E-mail: ctomaz@unb.br \\ Research supported by CAPES/DAAD/PRO BAL (No. 058/98). \\ J.E. Frank is the recipient of \\ a PhD fellowship from CAPES.}

Received May 30, 2000

Accepted September 13, 2000

\section{Abstract}

Several studies have documented that emotional arousal may enhance long-term memory. This is an adaptation of a paradigm previously used in North American and European samples in investigations of the influence of emotion on long-term retention. A sample of 46 healthy adults of high and low educational levels watched a slide presentation of stories. A randomly assigned group watched a story with an arousing content and another group watched a neutral story. The stories were matched for structure and comprehensibility and the set and order of the 11 slides were the same in both conditions. Immediately after viewing the slide presentation, the participants were asked to rate the emotionality of the narrative. The arousing narrative was rated as being more emotional than the neutral narrative $(t(44)=-3.6$, $\mathrm{P}<0.001)$. Ten days later subjects were asked to remember the story and answer a multiple-choice questionnaire about it. The subjects who watched the arousing story had higher scores in the free recall measure $(t(44)=-2.59, \mathrm{P}<0.01)$. There were no differences between groups in the multiple-choice test of recognition memory $(t(44)=0.26)$. These findings confirm that an emotional arousing content enhances longterm declarative memory and indicate the possibility of applying this instrument to clinical samples of various cultural backgrounds.
Key words
- Memory
- Emotion
- Stories
- Brazilian

\section{Introduction}

It is well known that memories of the happy and sad moments seem more resistant to the decay of time than other less striking events. Evidence from laboratory studies have similarly shown that memory retention is enhanced by increasing the emotional content of information in both normal (1) and brain-damaged subjects (2). These findings suggest that emotional arousal produced by certain situations can promote memory storage (3).
Studies on emotion have shown that particular qualities of pictures may elicit an emotional response that varies according to the valence (positive to negative) and in the arousing property of the stimuli (from neutral to exciting) (4). The arousing property of the emotional state produces both memory enhancement and memory inhibition. Intense emotional experience, such as in traumas, may cause psychogenic amnesia of lasting quality (5). In the present study we are concerned with the enhancing effects of emotional arousal on declarative memory (con- 
scious recollection of information) in humans. The study follows a line of research that examines the retention of information of an emotional experience which is not of traumatic intensity and involves visual and verbal modality.

Different instruments and stimuli have been used in studies of emotional memory, such as neutral and emotional pictures $(1,6)$, emotional facial expressions (7), film clips (8), and stories (9). The recall of narratives has been employed in a number of memory assessments and is considered a useful measure to assess recall and recognition (10).

The choice of memory measures and research instruments for this type of study poses a challenge in terms of internal and external validity because different stimuli are usually employed under experimental and control conditions. The different quality of the materials may confound the main effect and limit generalization. Also, cultural factors may affect the way emotional experiences are appraised (11). Therefore, it is important to choose instruments that are valid for a particular population.

The aim of the current study was to determine whether long-term retention of an emotionally arousing story is stronger than retention of a neutral story. We employed an adaptation to a Brazilian sample of stories that have been used in several experiments with patients and healthy adults involving the enhancing effects of emotion on memory $(9,12-14)$. It is a memory measure of two short stories presented with slides accompanied by a narrative. One of the stories tells about an accident and has a more arousing content than the other. The set of slides is the same in both conditions. This type of material has been useful in demonstrating the emotional effect on long-term declarative memory in research with patients who suffer from Urbach-Wiethe disease, a degenerative disease that damages the amygdala (12), in studies with amnesic patients $(2,13)$, and in the investigation of the noradrenergic arous- ing effect on memory (14).

As Cahill and McGaugh (9) state, these stories are matched as closely as possible. This offers better control for examination of the main effect, i.e., the emotional content, and not of the effect of the novelty of the material, the quality of the different visual stimuli used in the experimental conditions or a "story effect".

The location and the "actors" were taken from a Brazilian middle-western community and the text was adapted to the local culture. The subjects were drawn from a variety of cultural backgrounds in order to represent the diversity of local population.

\section{Subjects and Methods}

\section{Subjects}

The sample consisted of 46 healthy subjects (29 females and 17 males) with elementary $(\mathrm{N}=24)$, secondary $(\mathrm{N}=9)$ and college $(\mathrm{N}=13)$ educational level, with an urban, urban periphery and rural background. Mean age was 29 years (range: $18-47$ years). Subjects were volunteers recruited on the university campus, and at their work sites.

\section{Material}

The instruments used by Cahill and McGaugh (9) and by Adolphs and co-workers (12), kindly made available to us by Larry Cahill, were adapted and kept as close to the original as possible. Slides 1, 2, 4, 5, 6, 9,10 , and 11 were new pictures taken locally. An effort was made to keep the characters (age, physical appearance and type of clothing) and the overall quality of the scenes similar to the ones used by Cahill and McGaugh (9). The three slides originally used by Cahill and McGaugh and included in this research were: slide 3 - father working in the laboratory, slide 7 - physicians in the emergency ward, and slide 8 - badly injured feet. Each slide was presented for approxi- 
mately $10 \mathrm{~s}$. The stories tell about a mother and son going to visit the father's workplace. The slides are the same but there was a difference in the story content (see Table 1). In the neutral version, on their way to visit the father, they pass by a car accident that calls the attention of the child. In the hospital, where the father works, the child participates in an emergency drill. In the arousal version the child suffers a bad car accident on his way to visit his father and is critically hurt. He is operated upon at the emergency hospital. According to previous findings $(9,12)$, the arousing story can be divided into 3 phases, with the second phase (slides 5-8) being the emotionally stronger phase of the story. This phase is about the child's hospitalization including a photo of the boy's badly hurt legs and the surgery ward.

The same person made the narration in both conditions, played on a tape recorder in a flat and unemotional voice. The structure of the phrases was similar in both conditions. The slides were adapted to the local environment. Each slide was presented for approximately $10 \mathrm{~s}$.

A similar version of the questionnaire for the 11-slide sequence used by Cahill and McGaugh (9) was translated into Portuguese. The questionnaire has 5 to 9 items about each slide, with a total of 74 multiple-choice questions. The order of the questions was kept the same for all subjects, because previous findings have indicated that randomizing the order of the questions did not influence the total score in either condition (9).

The emotional rating scale consisted of a 0 to 10 scale printed on paper where the subjects marked the score corresponding to their opinion about the level of emotionality of the story. A score of 0 indicates "not emotional", and a score of 10 indicates "highly emotional".

The scoring system for story recall followed the criteria used to score most memory tests for stories (10). Each slide narration was separated into segments and subjects received a point for recall of each segment (see Table 1). The recall of each segment earned 1 point; for example, for slide 1 the subject could earn up to 3 points, plus additional points for accurate description of physical details such as "the boy was carrying a ball" (slide 1), "the mother, a lady wearing a red blouse" (slide 1), "mother and son were walking side by side, or arm in arm" (slide 2). The recall could have different wording from the original phrases but had to convey the same idea, a synonym or a phrase with the same meaning. The narration was segmented according to criteria referring to the content and structure of the narration, such as main idea (objective, central idea of the slide, who), action (what happened), complement to the action or to the main idea (to whom, what, how) and time complement (when, after or before). Any spontaneous addition of accurate details, not stated by the narrator of the stories, such as color of clothing, physical appearance of the characters and their location in space and in relation to each other, received a correct score. We scored these additional details because they reflected increased visual memory of the pictures. The organization and order of the recall were not considered in the scoring. The investigator did the scoring.

\section{Procedure}

Subjects were randomly assigned to the arousing condition or to the neutral condition. The two groups were equivalent in terms of educational level and gender. They were initially submitted to a screening interview for any health problems, drug use, sensory disability or signs of mental retardation. In the first session they watched the slide show and immediately afterwards answered the emotional rating scale on the story. Ten days later they were asked to remember the story and to answer the multiple-choice questionnaire about the story.

In both conditions the subjects were told 
Table 1 - Narrative that accompanied the slides.

Arousal version in italics.

\begin{tabular}{clr}
\hline Slide & Neutral & Arousal version \\
\hline 1 & A mother and her son are leaving home in the morning. & Same as neutral. \\
2 & She is taking him to visit his father's workplace. & Same as neutral. \\
3 & The father is the chief laboratory technician at a nearby hospital. & Same as neutral. \\
4 & They check before crossing a busy road. & Same as neutral.
\end{tabular}

5 While walking along, they pass the scene of a minor accident, which the boy finds interesting.

While crossing the road, the boy is struck by a runaway car, which critically injures him.

6 At the hospital, staff are preparing for a practice disaster drill, which the boy will watch.

At the hospital, the staff prepare the emergency room, to which the boy is rushed.

$7 \quad$ All morning long, surgeons practiced the standard disaster drill procedures. All morning long, surgeons struggled to save the boy's life.

8 Special make-up artists were able to create realistic injuries on actors for the drill.

Specialized surgeons were able to successfully reattach the boy's severed feet.

9 After the drill, while the father stayed with the boy, the mother left to phone her other child's preschool.

After the surgery, while the father stayed with the boy, the mother left to phone her other child's preschool.

10 Running late, she phones the preschool to tell them she will soon pick up her child.

Feeling distraught, she phones the preschool to tell them she will soon pick up her child.

11 Heading to pick up her child, she hails a taxi at the number nine bus stop.

Same as neutral.

Portuguese version. Bars indicate scoring marks. Arousal version in italics.

1 A mãe e o filho/estão saindo de casa/pela manhã.

2 Ela está levando o filho/para visitar/o lugar onde o pai trabalha.

3 O pai/é um técnico de laboratório/no hospital de urgências.

$4 \quad$ Eles/olham antes de atravessar a rua/movimentada.

5 No caminho,/eles passam por uma batida,/e o menino/para e olha interessado. No caminho,/quando atravessam a rua,/o menino/sofre um acidente terrível,/e fica gravemente ferido.

6 No hospital,/os médicos/estão se preparando para um treinamento no atendimento de emergência,/e o menino foi convidado a observar. No hospital,/os médicos/preparam a sala de emergência,/para onde o menino foi levado.

7 Por toda a manhã,/os médicos/fizeram o treinamento de emergência. Por toda a manhã,/os médicos/lutaram para salvar a vida do menino.

8 Os artistas/usaram pintura para imitar ferimentos/no treinamento de emergência.

Os médicos/costuraram/os pés decepados do menino.

9 Após o treinamento,/enquanto o pai ficou com o menino,/a mãe saiu para telefonar/para a escolinha do seu outro filho.

Após a cirurgia,/enquanto o pai ficou com o menino,/a mãe saiu para telefonar/para a escolinha do seu outro filho.

10 Ela estava atrasada,/e telefonou para a escolinha/para avisar que logo iria apanhar o filho.

Ela estava nervosa,/e telefonou para a escolinha/para avisar que logo iria apanhar o filho.

11 Ela está chamando um taxi/no ponto do ônibus no 9/para ir apanhar o filho. Same as neutral. 
that we were interested in knowing how people pay attention to stories. They were told that they were going to watch a slide presentation accompanied by a short phrase narrating the story played on the tape recorder. They were instructed to watch the show as if they were watching a TV program, paying attention to everything they were going to see and hear. We asked them to avoid making comments about the experiment with others. They were told that ten days later they would be doing the second part of the research and that we would be able to tell more about the research after the second session. None of the subjects indicated that they knew or suspected that their memory would be tested. Due to the diversified educational levels of the sample, the instructions varied somewhat in order to facilitate comprehension of the procedure. Their free recall was recorded on a portable tape recorder. Testing was individual in both sessions. With the exception of the university students, the experimenter read the questions to the subjects.

\section{Results}

The two groups differed in their mean recall of the stories. The subjects who watched the arousing story recalled more items of the story than the subjects who watched the neutral story. The mean recall score for the arousal group was $10.00 \pm 0.95$ versus $6.78 \pm 0.79$ for the neutral group $(t$ $(44)=-2.59, \mathrm{P}<0.01$ ) (Figure 1). The arousal group also rated the story more emotional than the neutral group $(t(44)=-3.6, \mathrm{P}<0.001)$ (Figure 2). The mean emotional rating was $7.34 \pm 0.29$ for the arousal group and $5.17 \pm$ 0.51 for the neutral group. A comparison between the mean recall of each phase of the stories (phases 1,2,3) revealed that subjects in the arousal group recalled significantly more information from the emotionally arousing middle phase of the story than did subjects from the neutral group $(t(39)=-4.13$,
$\mathrm{P}<0.001$ ) (Figure 3 ). The same was not observed for phases 1 and 3 .

There were no statistical differences between the total number of correct choices in the recognition questionnaire recalled by participants who heard the neutral narrative and the emotionally arousing narrative $(t$ $(44)=0.26)$. A phase by phase analysis, based on the Cahill and McGaugh procedure
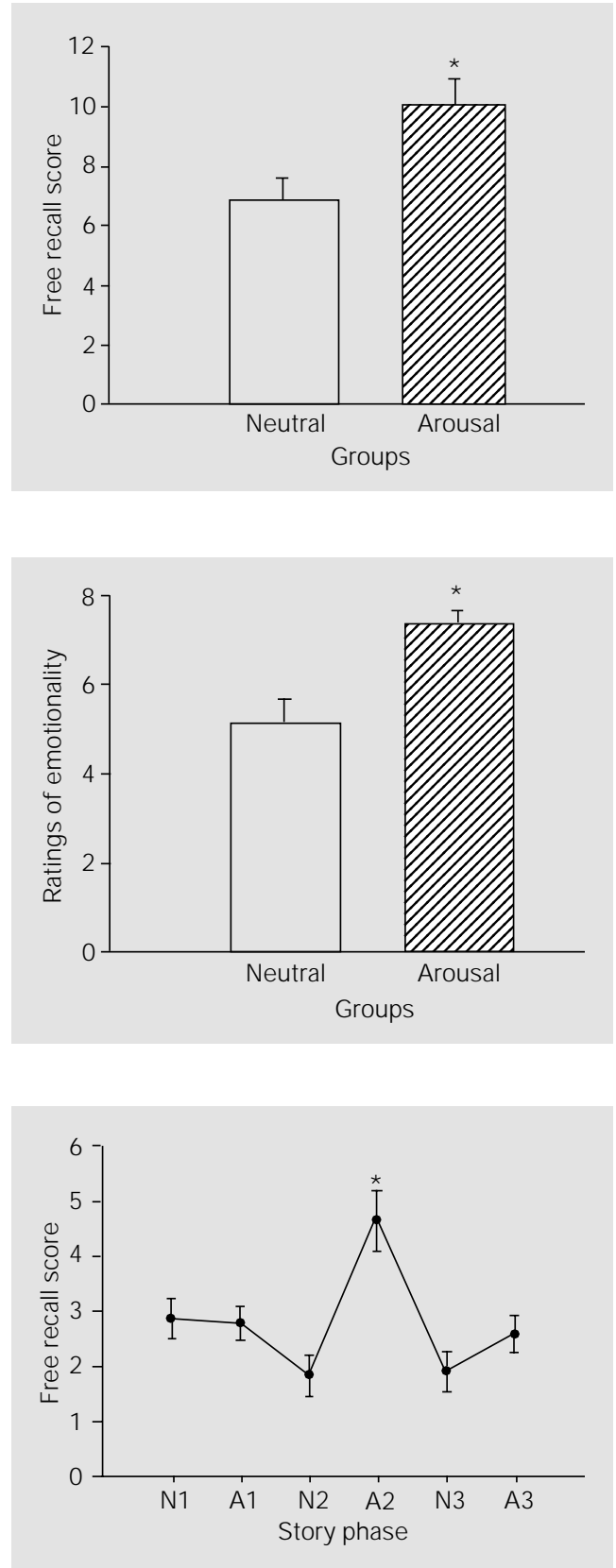

Figure 1 - Scores (mean \pm SEM) regarding the total amount of information free recalled by participants who heard the neutral narrative and participants who heard the emotionally arousing narrative. This recall test was performed 10 days after the subjects watched the slide show. $* \mathrm{P}<0.01$ compared to the neutral group (independent samples t-test).

Figure 2 - Ratings (mean \pm SEM) of emotionality for neutral and emotionally arousing narratives. The subjects were asked to rate their emotional reaction to the slide show immediately after its presentation on a scale of 0 (not emotional) to 10 (highly emotional). $* \mathrm{P}<0.001$ compared to the neutral group (independent samples t-test).

Figure 3 - Recall scores (mean \pm SEM) for each phase of the stories for participants who heard the neutral and the emotionally arousing narrative. $\mathrm{N}=$ Neutral; $A=$ arousal. The numbers after the letters indicate the phase of the story. Phase 1 corresponds to slides 1 to 4 , phase 2 to slides 5 to 8 , and phase 3 to slides 9 to 11. Phase A2 corresponds to the child's hospitalization, including a slide showing the surgically reattached legs. $* \mathrm{P}<0.001 \mathrm{com}$ pared to the neutral group phase 2 of the story (N2) (independent samples t-test). 
(9), also did not indicate any significant difference between the groups with respect to any of the three phases in the recognition questionnaire. However, the mean recognition score of slide 8 (a picture of a child's badly injured feet) disclosed a highly significant difference between the two groups ( $t$ $(44)=-2.88, \mathrm{P}<0.001)$, illustrating the enhancing effect of the arousing plot on recognition of this picture.

\section{Discussion}

The findings of the present study indicate that a narrative with high emotional content can enhance conscious free recall of information in humans, i.e., declarative memory. The fact that subjects in the arousal group rated the story more emotional than did the neutral group indicates a close relationship between emotionality and memory consolidation. These results are in agreement with extensive evidence from studies indicating that emotional arousal is associated with enhanced memory $(2,6,9)$.

Our results are not consistent with reported findings (9) on recognition of the most emotional part of the story (phase 2). The results on the recognition questionnaire may be due in part to the fact that this measure deals with distinct qualities of the stories and the pictures. For example, some questions ask about details that are not related to the main plot, such as spatial details about the pictures and identification of objects that appear in the picture but that are not mentioned in the narrative. Furthermore, these items are not equally distributed throughout the questionnaire, possibly reinforcing recall only for those slides that have more questions about the emotional part of the story, or more central details in the arousal condition.

It has been proposed that emotion enhances the retention of the central parts of the plot (15). If the whole slide, including peripheral and central aspects of the picture and plot, is enhanced by the arousal effect, than it is reasonable to expect that all details will be equally recalled. However, if the enhancement is more restricted to the emotional aspects of the plot, less relevant details such as the background of the picture that is not semantically linked to the event in the story will not be as well retained.

We found a remarkable difference between groups in recognition of slide 8 - a picture of badly injured feet. In the arousal version of the story this slide shows the boy's reattached feet after surgery. Subjects in the arousal condition obtained a significantly higher score for the items about this slide. This supports the possibility that in the present paradigm questions and visual elements more centrally related to the emotional plot were more affected by arousal.

A more detailed item analysis could improve the specificity of the questionnaire because of the restrictions indicated above and also in terms of cultural differences.

It is possible that the less educated subjects did not understand some of the questions due to unfamiliarity with this type of instrument or due to content problems. However, when the groups of college and elementary school subjects were analyzed separately, there was no significant difference between groups (neutral and arousing) in the recognition scores. This demonstrates that the enhancement is not likely to be a phenomenon of educational background. Therefore, despite the possible influence of education on the scores, we found that the results are important in terms of the main focus of this study.

Another restriction regarding the recognition measure refers to the sequencing of the items. We chose not to randomize the order of questions because evidence from previous findings (9) did not suggest that this was significant to the hypothesis. However, considering the characteristics of the present sample, we do not know how the order may have affected comprehension and the recog- 
nition process.

The free recall results in this heterogeneous sample strongly suggest that this instrument is a valid tool to examine emotional memory in subjects of varying educational levels. This consistency of findings across distinct cultural samples substantiates the universality of the emotional response to pictures and narratives and its influence on long-term retention under laboratory conditions. This supports the notion of biological mechanisms involved in this aspect of emotional memory. Our conclusion agrees with the view that the influence of emotion on memory is not a purely cognitive or affective phenomenon, but a property of an aroused state that involves subcortical and related physiological activation (9).

In light of present findings, many studies utilizing this picture/narrative-story paradigm can be conducted to analyze the nature of the emotional influence on memory. A number of investigations have dealt with the role played by structures in the medial part of the temporal lobe in the interaction between cognition and emotion. An extension of this paradigm to investigations with neurological and amnesic patients will contribute to defining the role of the neural network in enhancement of recall. Furthermore, our data indicate that this can be an interesting instrument for those who want to work with emotional memory in Brazil.

The considerable body of evidence regarding the enhancing effect of emotional content on declarative memory has an implication for memory rehabilitation. This may offer new strategies for improving recall in amnesic patients.

\section{Acknowledgments}

We are grateful to Dr. Larry Cahill for providing a version of the slides, protocols and narrative. We thank Adriana Leme for assistance in collecting data.

\section{References}

1. Taylor SF, Liberzon I, Fig LM, Decker LR, Minoshima S \& Koeppe R (1998). The effect of emotional content on visual recognition memory: A PET activation study. Neuroimage, 8: 188-197.

2. Hamann SB \& Cahill L (1997). Emotional perception and memory in amnesia. Neuropsychology, 11: 104-113.

3. McGaugh J L (1990). Significance and remembrance: The role of neuromodulatory systems. Psychological Science, 1: 15-25.

4. Lang P (1995). The emotion probe - Studies of motivation and attention. American Psychologist, 50: 372-385.

5. Markowitsch HJ, Kessler J, Van Der Ven C, Weber-Luxeburger G, Albers $M$ \& Heiss WD (1998). Psychic trauma causing grossly reduced brain metabolism and cognitive deterioration. Neuropsychologia, 36: 77-82.

6. Cahill L (1999). A neurobiological perspec- tive on emotional influence on long-term memory. Seminars in Clinical Neuropsychiatry, 4: 266-273.

7. Morris J S, Friston $\mathrm{KJ}$, Buchel CD, Frith $C D$, Young AJ , Calder AJ \& Dolan RJ (1998). A neuromodulatory role for the human amygdala in processing emotional facial expressions. Brain, 121: 47-57.

8. Lane RD, Reiman EM, Ahern GL, Schwartz GE \& Davidson RJ (1998). Neuroanatomical correlates of happiness, sadness, and disgust. American J oumal of Psychiatry, 154: 926-933.

9. Cahill L \& McGaugh J L (1995). A novel demonstration of enhanced memory associated with emotional arousal. Consciousness and Cognition, 4: 410-421.

10. Lezak MD (1995). Neuropsychological Assessment. 3rd edn. Oxford University Press, New York.

11. Mauro R, Sato K \& Tucker J (1992). The role of appraisal in human emotions: a cross-cultural study. J ournal of Personality and Social Psychology, 62: 301-317.

12. Adolphs R, Cahill L, Schul R \& Babinsky R (1997). Impaired declarative memory for emotional material following bilateral amygdala damage in humans. Learning and Memory, 4: 291-300.

13. Hamann S, Cahill L, McGaugh J L \& Squire LR (1997). Intact enhancement of declarative memory for emotional material in amnesia. Leaming and Memory, 4: 301309.

14. Cahill L, Prins B, Weber M \& McGaugh J L (1994). B-Adrenergic activation and memory for emotional events. Nature, 307: 702-704.

15. Heuer F \& Reisberg D (1992). Remembering emotional events. Memory and Cognition, 20: 277-290. 